\title{
Studerendes case-undersøgelser som omdrejningspunkt for forskningsbaseret holdundervisning
}

\author{
Nina Bonderup Dohn, lektor, Institut for Design og Kommunikation, SDU. \\ Birgitte Madelung, leder af Center for Universitetspaedagogik og Didaktik, \\ Det Humanistiske Fakultet, $K U$.
}

\section{Reviewet artikel}

Artiklen indledes med en diskussion af, hvori forskningsbaseret undervisning (FU) består. Vi bestemmer FU som undervisning, hoor studerende involveres som aktive deltagere i processen med at producere ny viden ved brug af forskningsmetode. Vores overordnede forskningsspørgsmål lyder: Hvilke muligheder giver et didaktisk design baseret på, at de studerende inddrages som bidragydere til forskningsprocessen, for at realisere de forskellige begrundelser for forskningsbaseret undervisning? Hvilke problemstillinger viser der sig i forsøget herpå? Spørgsmålet undersøges med fokus på læringsteoretiske begrundelser og filosofiske begrundelser for FU. Vi rapporterer resultater fra et følgeforskningsprojekt $i$ et undervisningsforløb, designet ud fra vores bestemmelse af FU. I diskussionen argumenterer vi for, at de læringsteoretiske begrundelser har rimelige muligheder for at kunne realiseres med det didaktiske design, mens de filosofiske begrundelser kræver mere understøttelse. Resultaterne peger på en række problemstillinger og barrierer for realiseringen af FU (i en bestemmelse som vores) og af begrundelserne for FU. Blandt disse er, at det didaktiske design indebærer en uvant arbejds- og studieform for de studerende, at der kan være en spænding mellem studieordningens faglige mål og FU ( $i$ en bestemmelse som vores), og at studerendes instrumentalistiske, erhvervsrettede mål kan være en barriere for realisering af de filosofiske begrundelser for FU.

\section{Introduktion}

Undervisning på universiteterne adskiller sig fra undervisning på andre uddannelsesniveauer og -institutioner ved at være forskningsbaseret. Det står i Universitetsloven fra 2011, og Bekendtgørelse $n r .1402$ fastsætter som et af sine akkrediteringskriterier for nye og eksisterende universitetsuddannelser, at "Uddannelsen er baseret på forskning og er knyttet til et aktivt forskningsmiljø af høj kvalitet". Bekendtgørelsen uddyber dette kriterium med et antal punkter, der på indholdssiden fastslår, at de studerende skal erhverve viden, færdigheder og kompetencer "baseret på forsk- 
ning". De øvrige punkter angår undervisernes og uddannelsesplanlæggernes kvalifikationer andetsteds end undervisningen (de skal være forskere) og uddannelsens tilknytning til et forskningsmiljø.

Taget som definition på 'forskningsbaseret undervisning' (FU) er bekendtgørelsens punkter oplagt mangelfulde. De definerer udelukkende, hvad der forstås ved 'basering' i en undervisningsekstern forstand, men forholder sig ikke til selve 'undervisningen', blot indholdet er 'baseret på forskning' (hvad undervisning på alle uddannelsesniveauer kan siges at være). Som vurderingskriterier for, om en institution kan forventes at levere FU (i en mere udfoldet bestemmelse), er punkterne også problematiske: Den implicitte præmis er her, at punkterne udgør nødvendige betingelser, der tilsammen sikrer eller sandsynliggør, at FU finder sted. Det er umuligt at vurdere rimeligheden af denne implicitte præmis, så længe den udfoldede bestemmelse ikke er givet. Som anvisning til den enkelte underviser eller uddannelse for, hvordan konkret undervisning skal tilrettelægges og afvikles, er punkterne ubrugelige - det er netop det, hvortil der savnes en mere udfoldet bestemmelse.

Hvori en sådan 'mere udfoldet bestemmelse' skal bestå er et tilbagevendende emne i diskussioner om universitetspædagogik og om universitetets rolle i nutidens samfund. I næste afsnit giver vi et kort begrebsafklarende rids og formulerer vores egen 'mere udfoldede bestemmelse'.

\section{Begrebsafklaring og forskningsfokus}

De universitetspædagogiske diskussioner om FU går både på, hvad termen mere præcist dækker over, og på, hvad der er relevante begrundelser for, at undervisning på universitetet skal være forskningsbaseret. Hvad det sidste angår, så spænder begrundelserne fra relativt instrumentalistiske kompetencebetragtninger til filosofiske overvejelser om realisering af universitetets ide.

I den instrumentalistiske ende argumenterer Brew (2007) for, at evnen til rationelt at undersøge og træffe velbegrundede beslutninger om givne problemstillinger er essentielt for de studerende i deres fremtidige jobs, og at de af denne grund må lære forskningsmetode. I den filosofiske ende henviser eksempelvis Feldt (2011) og Elton (2005) til Humboldts klassiske ide om universitetet som et sted, hvor forskning og undervisning i enhed med hinanden underlægger sig udvikling af videnskabelig viden og altid "im Forschen bleiben" (Humboldt, 1809/10). Imellem disse begrundelser ligger Barnetts identitetsfokuserede overvejelser om, at vi lever i en 'superkompleks' tid (Barnett, 2000; 2007), hvor der ikke gives endegyldige sandheder, og hvor det derfor er nødvendigt for studerende at lære at leve med usikkerhed som grundbetingelse. Uddannelse "in the spirit of research" (Barnett, 2007, s. 127) støtter de studerende heri. Ligeledes ligger der mellem yderpolerne et spænd af læringsteoretiske argumenter, hvis fælles kerne er, at studerende ved at involvere sig i 'inquiry-based 
learning', erhverver sig en dybere og mere omfattende (teoretisk/praktisk) forståelse af fagets indhold, problemstillinger og undersøgelsesmetoder (Illeris, 2004; Kolb, 1984; Jenkins et al., 2003; Colbeck, 2004).

Diskussionerne om, hvad FU er, bunder til dels i - men forvirres også i høj grad af at faglige discipliner har varierende (implicitte) forståelser af, hvad 'forskning' og 'undervisning' er, og i forlængelse heraf har forskellige traditioner for, hvordan forskning bedrives, og undervisning og læringsaktiviteter tilrettelægges og gennemføres (Healey, 2005). Forvirringen bliver ikke mindre af, at de engelske begreber 'research' og 'inquiry' dækker bredere end det danske 'forskning', eller af, at den angelsaksiske diskussion ofte formuleres i termer af 'mødet' mellem forskning og undervisning (the research-teaching-nexus: Healey, 2005; Elton, 2005; Verburgh et al., 2007), frem for i specifikke krav til forskningsbasering. I den forbindelse kunne man se bekendtgørelsens punkter som udtryk for en angelsaksisk tænkning, idet de blot angår sikringen af, at forskning og undervisning mødes. Vores påpegning af manglerne ved disse punkter er på den anden side udtryk for en opfattelse af, at der, når man taler om basering af undervisning på forskning, implicit ligger en forventning om, at der skal stilles krav til dette møde, og at ikke alle typer møder er relevante.

Forskellighederne discipliner og sprog imellem er delårsag til den grundlæggende uklarhed, der hersker mht. hvilke betingelser, der må opfyldes, for at undervisning kan siges at være forskningsbaseret. I Dohn \& Dolin (2013) giver vi et overblik over, hvilke elementer der fremhæves forskningsmæssigt og samfundspolitisk (inklusive i bekendtgørelsen) som forankringspunkter for FU. Med 'forankringspunkter' menes her ikke, at elementet i sig selv tænkes at give FU, men at fortalerne for elementet mener, at der skal stilles krav til dette element, for at der kan blive tale om FU. Dvs. at nødvendige betingelser for FU skal formuleres i relation til dette element (samt evt. også til andre af elementerne). Overordnet set er de fire elementer: undervisningen, underviseren, de studerende og uddannelsen. For flere af elementerne er der underforankringspunkter, således at det er bestemte aspekter af elementet, der stilles krav til.

Dette giver følgende liste:

1. Undervisningen: i) indhold og ii) form. Betingelser for FU formuleres fx som undervisning, der i) beskæftiger sig med ny forskningsviden og/eller ii) anvender eller eksemplificerer forskningsmetode.

2. Underviseren: aktiviteter og kvalifikationer i) andetsteds og ii) i undervisningen. Betingelser for FU formuleres fx som undervisning i) forestået af en aktiv forsker inden for feltet, eller ii) hvor forskeren inddrager sin forskning i undervisningen og/eller de studerende i sin forskning.

3. De studerendes aktivitet. Betingelser for FU formuleres $\mathrm{fx}$ som undervisning tilrettelagt, så de studerende arbejder forskningsmæssigt ved at i) anvende fagets teori og forskningsmetoder på relevante problemer, evt. for at ii) producere ny viden. 
4. Uddannelsens organisering. Betingelser for FU formuleres fx om undervisning, der pågår på en uddannelse, der er tilknyttet et aktivt forskningsmiljø.

Forankringspunkterne, især med underforankringspunkter, kan resultere i overlappende betingelser. En betingelse formuleret i relation til 3i) vil eksempelvis samtidig berøre 1ii). Dette er et udtryk for, at listen sammenfatter punkter i diskussionen til et overblik, og at ikke alle deltagere i diskussionen er enige om alle fire elementer. Bekendtgørelsens krav går således kun på 2i), 4) og en svag version af 1i).

I det forskningsprojekt, vi her rapporterer fra, forstås FU ud fra forankringspunkterne 1i), 1ii), 3i) og 3ii). Vores 'mere udfoldede bestemmelse' af FU er nemlig, at FU er undervisning, hvor studerende involveres som aktive deltagere i processen med at producere ny viden ved brug af forskningsmetode. ${ }^{1}$ Med afsæt i denne bestemmelse lyder vores overordnede forskningsspørgsmål: ${ }^{2}$

Hvilke muligheder giver et didaktisk design baseret på, at de studerende inddrages som bidragydere til forskningsprocessen, for at realisere de forskellige begrundelser for FU? Hvilke problemstillinger viser der sig i forsøget herpå?

For overskuelighedens skyld gengives begrundelserne her i punktform:

A. Kompetenceorienterede: De studerende får bestemte generelle undersøgelsesog evalueringskompetencer (Brew).

B. Læringsteoretiske: De studerende erhverver sig dybere og mere omfattende (teoretisk/praktisk) forståelse af fagets indhold, problemstillinger og undersøgelsesmetoder (bl.a. Illeris, Jenkins).

C. Identitetsfokuserede: De studerende lærer at leve med usikkerhed som grundbetingelse (Barnett).

D. Filosofiske: Realisering af universitetets ide (Humboldt).

Vi har undersøgt forskningsspørgsmålet i relation til et undervisningsforløb designet ud fra vores bestemmelse af FU. Undervisningsforløbet vægtede begrundelse B og D, og forskningsspørgsmålet er derfor kun undersøgt i forhold til disse. Det, der mere konkret blev sigtet på at opnå i forløbet, var, at de studerende

- B: fik dybere og mere omfattende forståelse af

1. Forskningsmetode i praksis.

2. Fagets teori.

- D: var med til at realisere universitetets ide ved:

- Produktion af ny viden til faget.

\footnotetext{
${ }^{1}$ Den konkrete form, deltagelsen vil tage, og det bidrag, de studerende kan forventes at levere, vil afhænge af uddannelsesniveauet. Healey \& Jenkins (2009) giver mange eksempler på denne type FU på forskellige BA-studier.

${ }^{2}$ Vi forventer at undersøge dette spørgsmål i flere delstudier. Her rapporteres fra ét sådant delstudie.
} 
- Oplevelsen af at være deltagere i et forskningsfællesskab i universitetspraksis.

\section{Undervisningsforløbets didaktiske design}

Den konkrete case var det meget teoritunge fag Webmedieret kommunikation og interaktion på cand.it.-studiet i Webkommunikation, Syddansk Universitet, afviklet af to undervisere i efteråret 2011 med 24 studerende. FU-aktiviteten var inspireret af Akhurst (2006) og lod de studerende producere ny viden til faget gennem undersøgelse af cases, som de havde adgang til gennem de praksissammenhænge, de indgik $\mathrm{i}$ inden for eller uden for universitetet. Første undervisningsgang fik de studerende til opgave 2 og 2 i løbet af 14 dage at træffe interviewaftale med en person i deres netværk, som arbejdede med webmedieret kommunikation. De fik en introduktion til interviewmetode i en undervisningstime og fik henvisninger til metodelitteratur.

De studerende rapporterede deres cases både skriftligt og mundtligt. Efter hver mundtlig case-præsentation diskuterede holdet teoretiske perspektiver på casen. Underviserne henviste sidenhen til nogle af case-præsentationerne ved gennemgang af ny teori. I den afsluttende undervisningsgang opsummerede underviseren fagets teori gennem relatering til de studerendes cases. Den skriftlige case-præsentation var en todelt portfolioopgave. Den ene del bestod i en case-beskrivelse på en e-læringsplatform. Den anden del var i sædvanligt opgaveformat og bestod i en redegørelse for metodologiske valg. Intentionen med case-beskrivelserne på e-læringsplatformen var, at der - som aktiviteten gentages i flere iterationer - ville blive opbygget en pool af helt up-to-date case-beskrivelser, som ville kunne anvendes i fremtidige undervisningssammenhænge og evt. indgå som datamateriale for studenter- og forskningsprojekter.

\section{Metode}

Følgeforskningen på undervisningsforløbet blev forestået af artiklens to forfattere i samarbejde. Artiklens førsteforfatter er den ene af underviserne på forløbet, mens artiklens andenforfatter deltog i projektet som eksternt tilknyttet. Samarbejdet havde til formål at sikre, på den ene side at projektet var informeret af det nødvendige insider-detailkendskab til undervisningsforløbet, og på den anden side at der bibeholdtes den nødvendige outsider-neutralitet i fremstilling og behandling af data. Samarbejdet var inspireret af den form for aktionsforskning, der betegnes interaktiv forskning (Svensson et al., 2002; Svensson \& Nielsen, 2006).

Projektet havde forskellige typer data:

- De studerendes portfolioopgaver.

- Et spørgeskema, som de tilstedeværende studerende (18 ud af 24) udfyldte sidste undervisningsgang. Spørgeskemaet spurgte i en kombination af åbne og lukkede spørgsmål til de studerendes oplevelse af, hvordan case- 
undersøgelserne havde bidraget til, at de erhvervede sig metodekompetence, forståelse af fagets teori og ny viden (hhv. B1, B2 og D1), og til deres syn på at casen ville indgå i en case-bank (relateret til D2).

- 5 opfølgende interviews. De studerende blev udvalgt pba. spørgeskemaundersøgelsen, ikke som repræsentative for holdet, men mhp. at få fremstillet og uddybet så bredt et spænd af synspunkter på de fire punkter som muligt.

Kombinationen af spørgeskemaundersøgelsen og interviews gjorde det muligt både at få holdets synspunkter repræsenteret og at få dybdegående begrundelser for typer af synspunkter. Spørgeskema- og interviewsetup og databehandling blev lavet, så de studerende var anonyme for underviseren.

Spørgeskemaets åbne spørgsmål gav anledning til kvalitative svar. Dem har vi kodet i fællesskab for bedst muligt at sikre objektivitet - forstået som intersubjektiv, argumenteret enighed - transparens og velbegrundethed af kodningen. Koderne blev valgt ved gennemlæsning med afsæt i forskningsspørgsmålet med fokus på B1, B2, D1 og D2. Endvidere gik en del udsagn igen om detaljer i forløbet, som var vigtige i forhold til planlægning af fremtidige forløb. Disse udsagn gav anledning til tilføjelsen af to yderligere koder. Koder med eksempler og hyppighed præsenteres i resultatafsnittet. Interviewene forkodede vi hver for sig og endeligt i fællesskab.

Portfolioopgaverne er af underviseren behandlet som selvstændige data om art og niveau af de studerendes faglige og metodologiske forståelse. De enkelte studerendes opgaver er ikke koblet direkte med spørgeskema- og interviewudsagn, da det ville underminere deres anonymitet over for underviseren. I stedet er generelle tendenser (fokuspunkter, typiske styrker og mangler) og divergenser noteret.

\section{Resultater}

I dette afsnit præsenteres, hvad følgeforskningen viser om realiseringen af B1, B2, D1 og D2. På den baggrund diskuteres i næste afsnit, hvad disse resultater betyder for vores overordnede forskningsspørgsmål. I hvert underafsnit tages afsæt i data fra de studerendes spørgeskemabesvarelse; disse data nuanceres gennem udsagn fra de opfølgende interviews og kontrasteres med den information, som portfolioopgaverne indeholder om spørgsmålet. I figur 1 og 2 og tabel 1 gengives resultaterne af de studerendes oplevelse af udbyttet af case-undersøgelserne. Tabel 2 gengiver i skematisk form indholdet af de kvalitative udsagn i spørgeskemaet. 


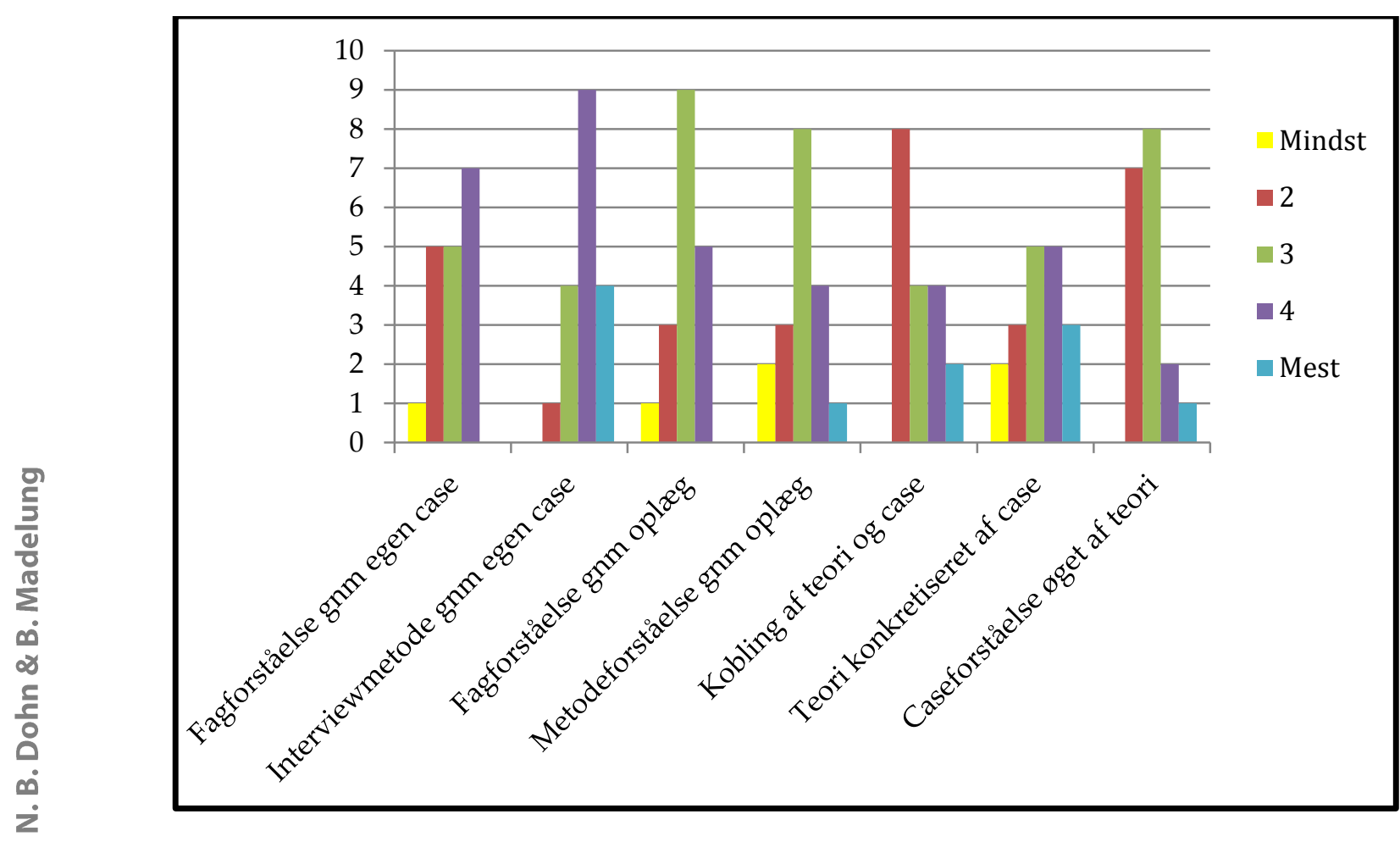

Figur 1. De studerendes oplevelse af udbyttet af case-undersøgelserne: faglig forståelse og interviewmetode. Y-aksen angiver antal studerende med svar i den pågxldende farve.

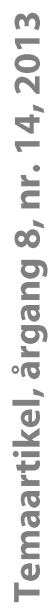

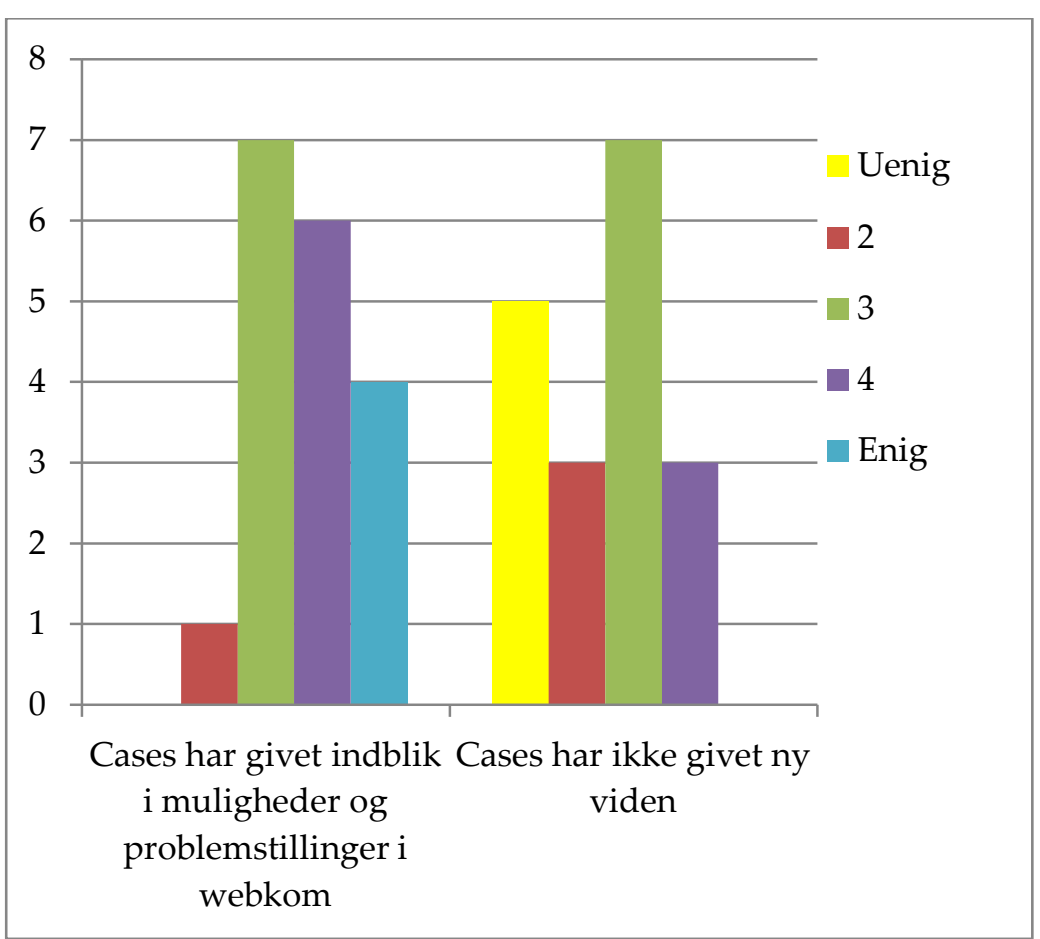

Figur 2. De studerendes oplevelse af udbyttet af case-undersøgelserne: indblik vs. ikke ny viden. Yaksen angiver antal studerende med svar $i$ den pågxldende farve. 


\begin{tabular}{|l|c|c|}
\hline Spørgsmål & Middelværdi & Spredning ( $)$ \\
\hline Fagforståelse gennem egen case & 3,0 & 0,9 \\
\hline Interviewmetode gennem egen case & 3,9 & 0,8 \\
\hline Fagforståelse gennem oplæg & 3,0 & 0,8 \\
\hline Metodeforståelse gennem oplæg & 2,9 & 1,0 \\
\hline Kobling af teori og case & 3,0 & 1,0 \\
\hline Teori konkretiseret af case & 3,2 & 0,8 \\
\hline Case-forståelse øget af teori & 2,8 & 0,8 \\
\hline Indblik i muligheder og problemstillinger & 3,7 & 1,0 \\
\hline Ikke givet ny viden & 2,4 & \\
\hline
\end{tabular}

Tabel 1. Middelværdi og spredning for udbytte.

\begin{tabular}{|c|c|c|}
\hline Kategori & Antal & Eksempler \\
\hline Læringsindhold & 23 & $\begin{array}{l}\text { Interviewteknik, analyse og formidling af case, refleksioner } \\
\text { over proces, case-unders } \emptyset \text { gelser giver mange vinkler på } \\
\text { kursets faglige indhold, ny viden }\end{array}$ \\
\hline $\begin{array}{l}\text { Læringsunderstøttende } \\
\text { arbejdsformer }\end{array}$ & 23 & $\begin{array}{l}\text { Præsentationskrav, feedback, på egen hånd, prøve noget nyt, } \\
\text { fællesskab på ny linje, god dynamik med } \emptyset \text { vrige studerende } \\
\text { ved fremlæggelse, interviews placering i semestret gjorde } \\
\text { kobling til teori svær (neg.) }\end{array}$ \\
\hline \multicolumn{3}{|l|}{$\begin{array}{l}\text { Kobling mellem teori og } \\
\text { praksis }\end{array}$} \\
\hline - $\quad$ Positivt & 10 & $\begin{array}{l}\text { Ny og anderledes måde at arbejde med viden og teori } \mathrm{i} \\
\text { praksis, indblik i webarbejders hverdag, teoretisk stof i } \\
\text { virkelighedsnær sammenhæng, underviser får stof til op- } \\
\text { summering af teori }\end{array}$ \\
\hline - Negativt & 15 & $\begin{array}{l}\text { Manglende teoretisk baggrund, manglende metodeteori, } \\
\text { kobling skete først ved sidste undervisningsgang }\end{array}$ \\
\hline Relevans af forløbet & 15 & $\begin{array}{l}\text { Info om arbejdsmarkedet, ideer til speciale, } \varnothing \text { ve præsentati- } \\
\text { onsteknik, indsigt i informants arbejdsområde }\end{array}$ \\
\hline Udfordringer & 43 & $\begin{array}{l}\text { Tidskrævende, tekniske vanskeligheder, manglende metode- } \\
\text { teori, i tvivl om opgavens indhold, finde en relevant person, } \\
\text { koordinering med gruppemedlem, interviews placering i } \\
\text { semestret gjorde kobling til teori svær }\end{array}$ \\
\hline \multicolumn{3}{|l|}{ Ejerskab } \\
\hline - $\quad$ Positivt & 16 & $\begin{array}{l}\text { Valgfrihed positivt, selv være med til at præge case fra start } \\
\text { til slut, positivt at kunne påvirke undervisningen, man kunne } \\
\text { fokusere på lige netop den og det, man ville, større interesse } \\
\text { fordi selvvalgt }\end{array}$ \\
\hline - $\quad$ Negativt & 2 & $\begin{array}{l}\text { [overstreget ordet 'selvvalgt' i spørgsmålet], underviserpro- } \\
\text { jekt - ikke ejet af mig }\end{array}$ \\
\hline \multicolumn{3}{|l|}{ Forståelse af formålet } \\
\hline - Positivt & 1 & $\begin{array}{l}\text { Mulighed for at afprøve sig selv i interviewsituation og i } \\
\emptyset v r i g t \text { arbejde på en mere forskningsorienteret måde }\end{array}$ \\
\hline - Negativt & 7 & $\begin{array}{l}\text { Formål var ikke klart, svært at se, hvad det skal bruges til, } \\
\text { tydeligere kobling til teori fra start havde været en fordel }\end{array}$ \\
\hline Syn på vidensdeling & 19 & $\begin{array}{l}\text { Helt fint, positivt at andre kan få gavn af ens arbejde, andres } \\
\text { case-undersøgelser giver mange vinkler på kursets faglige } \\
\text { indhold, ikke sikker på, hvad andre får ud af det - men ide- } \\
\text { en er super, opload til platform mhp. tilgængelighed frem- } \\
\text { over burde være underviserens opgave }\end{array}$ \\
\hline Ny viden & 2 & Højaktuel case giver relevans, ny viden \\
\hline
\end{tabular}

Tabel 2. Kvalitative udsagn fra spørgeskemaet. 


\section{B1: Forskningsmetode}

Besvarelser af såvel lukkede som åbne spørgsmål i spørgeskemaet peger på, at de studerende først og fremmest har set case-undersøgelserne som en træning i interviewmetode (figur 1 og tabel 2). Generelt mener de også at have haft et rimeligt udbytte på denne front. Således er der kun 1 af de 18, der svarer negativt på spørgsmålet, om arbejdet med egen case har bidraget til forståelse af interviewmetode. De studerende mener, at deres udbytte fortrinsvis er opnået gennem arbejdet med egen case og kun i mindre grad gennem de andres oplæg. Dette er ikke overraskende, eftersom oplæggene var fokuseret på formidling af casens indhold.

Flere studerende kommenterer, at de har savnet metodeteori (tabel 2). Givet at de havde fået en kort mundtlig introduktion og henvisning til litteratur, er det, der efterlyses, formentlig inddragelse af metodelitteratur som del af det behandlede pensum forud for planlægning og udførelse af de konkrete interviews. For andre studerende synes dette ikke at have været et problem. De opfølgende interviews tydeliggør forskellene: En del af de studerende har lavet interviews tidligere i deres uddannelse og trækker på erfaringer herfra. Nogle (men ikke alle) af disse studerende har også læst metodelitteratur i den forbindelse. Andre studerende havde aldrig lavet akademiske interviews før og følte sig uforberedte. Som illustreret af interviewcitater i Boks 1 kom denne følelse til udtryk både hos dem, der valgte at læse noget af den anbefalede metodelitteratur, og hos dem, der ikke gjorde det. Portfolioopgaverne bekræfter, at nogle af de studerende har haft behov for yderligere understøttelse på den metodologiske front.

Respondent A (læste selv Kvale): "hvis vi havde gennemgået hans [Kvales] principper i undervisningens... så tror jeg helt klart, jeg var blevet klædt bedre på".

Respondent C (læste ikke selv Kvale): "jamen jeg synes der manglede teori ... angående interviews... jeg har jo arbejdet med interviewteknik i min gamle stilling... så rent interviewmæssigt der kan jeg jo sagtens interviewe men igen problemet er at ... jeg ved reelt set ikke universitetets ... det jeg skal vide". (Interviewudsagn om metode).

\section{B2: Fagets teori}

Det mest klare resultat i forhold til dette punkt, er, at det varierer rigtigt meget (figur 1 og tabel 1+2). En del studerende har oplevet, at de forstod fagets indhold en del bedre gennem case-undersøgelserne, at teori og cases blev koblet godt sammen, og at fagets teori derigennem blev mere konkret. Hvorimod andre studerende stort set intet fagligt mener at have fået ud af casene og kun i ringe grad har set en kobling mellem teori og case. Kommentarer i de kvalitative udsagn i spørgeskemaerne spænder fra "Man får set det teoretiske stof i en mere virkelighedsnær sammen- 
hæng" til "Har først i dag kunnet se sammenhængen mellem casen og fagets teorier".

De opfølgende interviews bekræfter variationen i synspunkter, ligesom de nuancerer begrundelserne for dem. En studerende forklarer, at koblingen mellem fagets teori og dennes konkrete case i høj grad skete i den diskussion, der udspandt sig i forlængelse af den mundtlige case-præsentation. En anden studerende kommenterer, at case-undersøgelserne var meget relevante, fordi "det bliver koblet med noget praktisk" (Respondent A). En tredje siger derimod, at det har været svært at se sammenhængen mellem teori og cases før sidste undervisningstime, og begrunder det med, at oplægsholderne dårligt har kunnet inddrage teori, som de først har fået kendskab til senere i semestret.

Portfolioopgaverne vidner om, at alle studerende ved afslutningen af faget havde opnået en forståelse af den faglige sammenhæng mellem teori og cases. Der synes dog at være en tendens til, at de studerende, der på forhånd bedst beherskede de akademiske arbejds- og kommunikationsformer, fik mest fagligt ud af aktiviteten.

\section{D1: Ny viden}

Et flertal af de studerende har oplevet gennem case-undersøgelserne at få indblik i muligheder og problemstillinger i webmedieret kommunikation i dag; ligesom der er flere, der mener at have fået ny viden gennem aktiviteten, end der er, der mener det modsatte (figur 2). For at undgå bias blev spørgeskemaspørgsmålene dog ikke formuleret med en skarp skelnen mellem ny viden for den studerende og ny viden for forskningsfeltet, og de studerende har derfor meget muligt først og fremmest svaret på, om de mener at have lært noget nyt; ikke, om de mener at have produceret ny viden til feltet.

I de opfølgende interviews spørges de studerende direkte ind til, om de oplever, at de har bidraget til området webmedieret kommunikation og interaktion. Deres svar viser, at der også her er et spænd af opfattelser. To studerende svarer, at de ikke mener at have bidraget til fagområdet. Tre studerende svarer, at det mener de, de har, men det er tydeligt, at i hvert fald den ene udelukkende tænker på sit eget hold: "ja det mener jeg helt klart at jeg har... da vi var færdige med at præsentere vores ... kom der mange interesserede spørgsmål og så det var i hvert fald noget der blev brugt tid på den diskussion bagefter..." (Respondent A). En anden af de tre svarer omvendt, at han/hun ikke mener, der her og nu kan ses tendenser i casene, men at hvis der over tid opbygges en vidensbank af cases, "så tror jeg at akkumulationen ... vil kunne give nogle overordnede ... tendenspejlinger" (Respondent D).

De fleste skriftlige case-beskrivelser bærer præg af, at de studerende har haft lidt svært ved at se, hvad de skulle bruges til efterfølgende. Således har mange studeren- 
de lavet punktformede, meget deskriptive opregninger af fakta om interviewpersonens arbejdssituation. Muligheder og problemstillinger rapporteret af interviewpersonen gengives i de fleste tilfælde umedieret. Som interviewdata til en databank og som illustrationscases i fremtidig undervisning er materialet brugbart, men som deciderede forskningscases er kun de færreste anvendelige.

\section{D2: Deltagelse i forskningsfrllesskab}

Der er kun meget få data overhovedet, der indikerer noget om de studerendes syn på at være deltagere i et forskningsfællesskab. De sparsomme data er fortrinsvis at finde i) blandt de studerendes besvarelse af spørgsmål om deres syn på, at deres case vil kunne blive brugt i fremtidig undervisning, samt indirekte ii) i den usikkerhed, som flere tilkendegiver, over for formålet med at lave case-undersøgelser. De studerende synes stort set alle at være positive (fra lidt til meget) over for evt. 'genbrug' af deres case, men ingen synes at se sig selv som del af en større proces. Adskillige markerer snarere, at det er et underviseranliggende, som de ikke har nogen aktie i, eksempelvis: "Jeg har det dog ok med at I vælger at bruge vores cases" og "det er helt fint - og det vidste vi jo på forhånd". Flere udtrykker usikkerhed mht. hvad casen vil kunne bruges til af andre. Interviewene (samme udsagn som behandlet ifm. D1) bekræfter, at tanken om at være del af et forskningsfællesskab ikke har været fremherskende. Førsteforfatterens underviserindtryk fra processen er i overensstemmelse hermed: Langt de fleste vurderes at have set case-undersøgelserne som en aktivitet, hvis formål var at tilbyde de studerende læringsmuligheder. Kun ganske få, hvis overhovedet nogen, har tænkt på den som en deltagelse i et forskningsfællesskab.

\section{Diskussion}

Artiklens forskningsspørgsmål lød: Hvilke muligheder giver et didaktisk design baseret $p a ̊$ at de studerende inddrages som bidragydere til forskningsprocessen, for at realisere de forskellige begrundelser for FU? Hvilke problemstillinger viser der sig $i$ forsøget herpå? Grundet det konkrete undervisningsforløb, som forskningsspørgsmålet blev undersøgt i relation til, er det dog kun de læringsteoretiske (B1 og B2) og filosofiske (D1 og D2) begrundelser for FU, som resultaterne siger noget om. Det skal pointeres, at den konkrete implementering af det didaktiske design naturligvis har betydning for de studerendes opfattelse af FU-aktiviteten, så svagheder og mangler i implementeringen (såsom tekniske vanskeligheder ved e-læringsplatformen) kan påvirke resultaterne. Dette må tænkes med i diskussionen af forskningsspørgsmålet.

Kernen i de læringsteoretiske begrundelser (B) for FU, forstået bredt som 'inquirybased learning', er, at de studerende herigennem erhverver sig en dybere og mere omfattende (teoretisk/praktisk) forståelse af fagets indhold, problemstillinger og undersøgelsesmetoder (Illeris, 2004; Kolb,1984; Jenkins et al., 2003; Colbeck, 2004). Sammenfattende viser resultaterne, at de studerende mener at have opnået en rimelig grad af forståelse af og kompetence i forskningsmetode i praksis, mens det er me- 
re varierende, i hvor høj grad de oplever at opnå en større forståelse af fagets indhold gennem casene. Om det, de har lært ift. forskningsmetode og fagligt indhold, er mere, end de ville have lært gennem andre former for undervisning, er det i sagens natur svært at måle direkte. På den anden side synes det ret klart, både ud fra en teoretisk betragtning og ud fra det empiriske materiale, at involvering i undersøgelse af en egen case giver de studerende adkomst til en anden form for forståelse af forskningsmetode, end de ellers ville kunne have. Teoretisk finder dette udsagn belæg i teorier om betydningen af erfaring og praktisk kunnen for at kunne agere kompetent (Kvale, 1997; Dreyfus \& Dreyfus, 1986; Dohn, 2013). Empirisk understøttes udsagnet fx af flere af de positive udsagn om kobling mellem teori og praksis (jf. tabel 2). Hvad forståelsen af fagligt indhold angår, er det et tilbagevendende problem i et teoritungt fag som det, der her rapporteres fra, at de studerende savner konkrete ansatspunkter for teorien. Her er det førsteforfatterens underviservurdering - på baggrund af studenterudsagn i spørgeskema og interviews og i sammenligning med andre undervisningsforløb - at FU-aktiviteten trods alt har bidraget til at gøre fagets teori forståelig for flere af de studerende, end undervisningsaktiviteter, der ikke involverer et selvstændigt case-arbejde, ville have gjort.

Kernen i de filosofiske begrundelser for FU er, at universitetets ide realiseres gennem, at forskning og undervisning i enhed med hinanden underlægger sig udvikling af videnskabelig viden (Humboldt, 1809/10; Feldt, 2011; Elton, 2005). Sammenfattende viser resultaterne, at de fleste studerende mener at have fået ny faglig viden, men at de ikke nødvendigvis ser denne som 'produktion af ny viden til faget', ligesom de kun i ringe grad har opfattet aktiviteten som 'deltagelse i et forskningsfællesskab'. Disse resultater indikerer, at realiseringen af de filosofiske begrundelser kræver betydeligt mere understøttelse, end tilfældet var i dette undervisningsforløb.

Mindst lige så interessant som besvarelsen af, hvad følgeforskningen viser om mulighederne for at realisere B og D gennem det beskrevne didaktiske design, er imidlertid spørgsmålet om, hvilke problemstillinger den peger ud:

Den store spredning i de studerendes opfattelse af deres udbytte er et væsentligt resultat i sig selv, især koblet med den usikkerhed, flere af dem har følt mht. formålet med case-undersøgelserne. Disse forhold tyder på, at den krævede arbejds- og studieform er uvant for mange. Dette kan udgøre en stor barriere for realisering af begrundelserne for FU med et didaktisk design som det her anvendte.

Kvaliteten af portfolioopgaverne indikerer som nævnt, at de studerende, der på forhånd bedst beherskede de generelle akademiske arbejds- og kommunikationsformer, fik mest fagligt ud af FU-aktiviteten. Det er måske ikke overraskende, men minder dog om, at de læringsteoretiske begrundelser for FU ikke står alene, men fordrer didaktisk tænkning om differentierede studenterforudsætninger for at kunne realiseres. 
I forlængelse af de to foregående punkter giver flere studerende udtryk for, at caseundersøgelserne for dem var en måde at få indblik i fremtidige jobmuligheder (jf. tabel 2). Denne erhvervsrelatering er i overensstemmelse med de forholdsvis instrumentalistiske, erhvervsrettede mål for deres universitetsuddannelse, som flere af dem i uformelle samtaler giver udtryk for at have. Sådanne instrumentalistiske mål står i et umiddelbart spændingsforhold til de filosofiske begrundelser for FU og kan potentielt udgøre en barriere mod realiseringen af dem.

Resultaterne indikerer et behov for større metodologisk understøttelse af de studerende. Det er imidlertid diskutabelt, hvor meget tid der kan afsættes til metode i et fag, der ikke studieordningsmæssigt har fokus herpå. Denne problemstilling er udtryk for manglende sammenhæng mellem FU-aktiviteten og studieordningens læringsmål i det konkrete forløb. Den antyder mere generelt, at der kan opstå en spænding mellem konkrete faglige mål for et fag og realiseringen af FU (i en udfoldet bestemmelse), hvis fagene ikke er formuleret med inddragelse af denne bestemmelse.

I forlængelse af IV (og II) indikerer resultaterne, at de studerende har brug for mere hjælp til at strukturere deres selvstændige forskningsaktivitet og til at integrere det indhold, de producerer, med det øvrige faglige indhold. Dette tyder på, at den vægt, der lægges på de studerendes egen aktivitet i det beskrevne didaktiske design, må balanceres af krav til interaktion i timerne mellem studerende og underviser om det faglige og metodologiske indhold. Alternativt kan det didaktiske design ende med at få negativ indflydelse på realiseringen af de læringsteoretiske begrundelser for FU.

Flere af de nævnte problemstillinger rejser et bagvedliggende spørgsmål, nemlig om det enkelte fag som forankringspunkt for FU. Hvis vores udfoldede bestemmelse af FU lå til grund, ikke kun for undervisning i det enkelte fag, men for et undervisersamarbejde på tværs af flere fag og semestre og var ekspliciteret i studieordningen, ville det blive betydeligt lettere at imødegå problemstilling I, IV og V, idet man kunne arbejde med en progression i FU-arbejdsformen. Dette ville formentlig også hjælpe til at imødegå III, idet de filosofiske begrundelser for FU ville blive mere nærværende for de studerende, hvis de blev italesat i flere fag.

\section{Afsluttende bemærkninger}

I denne artikel har vi set på muligheder for og problemstillinger ved realisering af læringsteoretiske og filosofiske begrundelser for FU med et didaktisk design, der tager afsæt $i$ en bestemmelse af FU som undervisning, hvor studerende involveres som aktive deltagere i processen med at producere ny viden ved brug af forskningsmetoder. På den positive side begrænser vores resultater sig til konstateringen af, at muligheden for at realisere i hvert fald de læringsteoretiske begrundelser består. De mere udfoldede resultater er at finde på den negative side i påpegningen af en række problemstillinger. Vi har argumenteret for, at flere af disse ville kunne af- 
hjælpes, i fald vores bestemmelse af FU fik rod i studieordningen og blev lagt til grund for et undervisersamarbejde med fokus på en progression i FU-arbejdsformer på tværs af fag og semestre.

Afslutningsvis vil vi vende tilbage til listen over forankringspunkter i diskussionen om FU (afsnit 2). Vores bestemmelse af FU angår som nævnt forankringspunkterne 1 og 3: undervisningen og de studerendes aktivitet. Vores diskussion antyder imidlertid, at man ved at stille krav til 2 og 4 (hhv. underviseren og uddannelsens organisering) om organisering af uddannelsen omkring et undervisersamarbejde kan understøtte iværksættelsen af bestemmelsen bedre. Et evt. yderligere krav til underviseren kunne være, at denne skal initiere læringsaktiviteter, der integrerer de studerendes forskningsbidrag til et større hele, med henblik på at støtte de studerende i at opnå det fulde læringsmæssige udbytte af FU. Det bemærkes, at disse krav til 2 og 4 er noget anderledes - og meget mere specifikke - end Bekendtgørelsens kriterier. Bekendtgørelsens kriterier er alt for eksterne i forhold til de aktiviteter, som vores 'mere udfoldede bestemmelse' fordrer, og de fremstår derfor ikke som nødvendige betingelser, der sikrer eller sandsynliggør, at FU finder sted. ${ }^{3}$

Nina Bonderup Dohn, ph.d., lektor i Informationsvidenskab og indtil 31/12. 2012 Humanioras repræsentant $i$ Center for Universitetspædagogik på SDU. Hun har siden 1/6. 2011 været ansvarshavende redaktør på Dansk Universitetspædagogisk Tidsskrift. Hendes forskning ligger $i$ spændingsfeltet mellem erkendelsesteori og læringsteori med fokus både på filosofiske spørgsmål om, hvad viden og læring er, og på pædagogiske spørgsmål om didaktisk design af laringssituationer.

Birgitte Madelung, ph.d., var på tidspunktet for den rapporterede folgeforskning ansat som specialkonsulent ved Center for Universitetspæedagogik på SDU. Hun fungerede som kursusleder på Universitetspædagogikum og på en lang række universitetspædagogiske kurser. Hun arbejdede desuden med projekter vedrørende informationskompetence, feedback og sprogkompetencer. Siden 1/12. 2012 er hun ansat som leder af Center for Universitetspædagogik og Didaktik på Det Humanistiske Fakultet på KU.

\section{Referencer}

Akhurst, J. (2006). Blending research \& teaching in the classroom. Students researching students' quality of life. www.pnarchive.org/docs/doc/Akhurst CaseStudy I.doc (tilgået 18.07.12)

Barnett, R. (2000). Realizing the University in an age of supercomplexity. Buckingham: Open University Press.

Barnett, R. (2007). A will to learn. Berkshire: Open University Press.

Brew, A. (2007). Research and teaching from the students' perspective. I: International policies and practices for academic enquiry. International Colloquium, Winchester, UK, 19-21 april.

${ }^{3} \mathrm{Vi}$ vil gerne takke to anonyme reviewere for værdifulde kommentarer, der har hjulpet os til et klarere fokus i artiklen. 
Colbeck, C. (2004). "A cybernetic systems model of teaching and research production: Impact of disciplinary differences. I: Research and teaching: Closing the divide? International Colloquium, Winchester, UK, 17-19 marts.

Dohn, N. \& Dolin, J. (2013, in press). Forskningsbaseret undervisning. I: Rienecker, L., Stray, P., Dolin, J. \& Ingerslev, G. (red.): Universitetspædagogik. Frederiksberg: Samfundslitteratur.

Dohn, N. (2012). "Viden i praksis" - implikationer for it-baseret læring. Res Cogitans, Nr. 9.

Dreyfus, H. \& Dreyfus, S. (1986). Mind over machine. New York: The Free Press.

Elton, L. (2005). Scholarship and the research and teaching nexus. I: Barnett, R. (Ed.): Reshaping the university. Maidenhead: Open University Press, s.108-118.

Feldt. J. (2011). Den skønne undervisning. Undervisning set som videnskabelig dannelse. I: Feldt, J. \& Dohn, N. (red.) Universitetsundervisning i det 21. århundrede. Odense: Syddansk Universitetsforlag, s. 71-94.

Healey, M. \& Jenkins, A. (2009). Linking discipline-based research and teaching through mainstreaming undergraduate research and inquiry. http://resources.glos.ac.uk/shareddata/dms/7A6736F0BCD42A039D9A5CC4AC C7C16B.pdf (tilgået 14.02.13).

Healey, M. (2005). Linking research and teaching: Exploring disciplinary spaces and the role of inquiry-based learning. I: Barnett, R. (Ed.): Reshaping the university. Maidenhead: Open University Press, s. 67-78.

Illeris, K. (2004). Adult education and adult learning. Roskilde: Roskilde University Press.

Jenkins, A., Breen, R., Lindsay, R. \& Brew, A. (2003). Linking research and teaching in departments. York:. Higher Education Academy.

Kolb, D. (1984). Experiential learning. New York: Prentice Hall.

Kvale, S. (1997). InterView. København: Hans Reitzels Forlag.

Svensson, L., \& Aagaard Nielsen, K. (2006). Action Research and Interactive Research. Stockholm: Arbetslivinstitutet i Sverige.

Svensson, L., Brulin, G., Ellström, P.-E., \& Widegren, Ö. (2002). Interaktiv forskning. Stockholm: Arbetslivsinstitutet.

Verburgh, A., Elen, J., Lindblom-Ylänne, S. (2007). Investigating the myth of the relationship between teaching and research in higher education: A review of empirical research. I: Studies in Philosophy and Education 26(5), s. 449-465.

von Humboldt, W. (1809/10). Über die innere und äußere Organisation der höheren wissenschaftlichen Anstalten in Berlin. edoc.hu-berlin.de/miscellanies/g-texte30372/229/PDF/229.pdf (tilgået 18.07.12). 